\title{
PERSEPSI WISATAWAN MANCANEGARA TERHADAP BRAND PARIWISATA WONDERFUL INDONESIA
}

\author{
Diah Febrina \\ Fakultas Ilmu Komunikasi Universitas Pancasila \\ diah.febrina@gmail.com
}

Diajukan: 26-05-2018; Direview: 27-05-2018; Diterima: 14-06-2018;

\begin{abstract}
The phenomenon of tourism is a major phenomenon and increasingly shows a significant progress. The Government of Indonesia helped to build this industry by creating a brand of tourism for Indonesia, namely Wonderful Indonesia. This study aims to determine the perception of foreign tourists about the brand Wonderful Indonesia. Perception is measured through elements of the Wonderful Indonesia brand that consist of natural beauty, Indonesian culture, community friendliness, food and financial value. A total of 110 tourists were interviewed as respondents using a set of questionnaires. Results of the study reveals that $61 \%$ of tourists do not recognized the Wonderful Indonesia branding because they get little exposure to this brand. In general, the majority of respondents perceive that Indonesian nature is beautiful, interesting culture, friendly people, good food and cheap financial value for tourists.
\end{abstract}

Keywords: perception, tourism branding, Wonderful Indonesia

\begin{abstract}
Abstrak
Fenomena pariwisata merupakan sebuah fenomena besar dan semakin menunjukkan sebuah kemajuan yang signifikan. Pemerintah Indonesia ikut membangun industri ini dengan menciptakan sebuah brand pariwisata bagi Indonesia yaitu Wonderful Indonesia. Penelitian ini bertujuan untuk mengetahui persepsi wisatawan mancanegara tentang brand Wonderful Indonesia. Persepsi diukur melalui elemen-elemen dalam brand Wonderful Indonesia yang terdiri dari keindahan alam, budaya Indonesia, keramahan masyarakat, makanan dan nilai keuangan. Sejumlah 110 wisatawan telah diwawancara sebagai responden dengan menggunakan satu set kuesioner. Hasil kajian mendapati bahwa sejumlah 61\% wisatawan tidak mengetahui brand Wonderful Indonesia karena sedikit mendapat terpaan akan brand ini. Secara umum, mayoritas responden mempersepsi bahwa alam Indonesia indah, kebudayaan menarik, masyarakat yang ramah, makanan yang baik dan nilai keuangan yang murah bagi para wisatawan.
\end{abstract}

Kata Kunci : persepsi, brand pariwisata, Wonderful Indonesia

\section{PENDAHULUAN}

$\mathrm{F}$ enomena pariwisata saat ini ialah sebuah fenomena besar dan telah menunjukkan satu pertumbuhan yang menggairahkan (Yamashita et al. 1997; Goeldner \& Ritchie 2006; UNWTO 2017). Sampai dengan tahun 2016 pertumbuhan pariwisata di dunia terus berada pada perkembangan yang positif. Organisasi Pariwisata sedunia (UNWTO) pada tahun 2017 melaporkan bahwa kedatangan wisatawan internasional mengalami peningkatan secara global mulai dari 25 juta pada tahun 1950 ke 278 juta di tahun 1980 , 674 juta di tahun 2000 dan mencapai 1.235 juta pada tahun 2016.
Pertumbuhan positif ini merupakan sebuah hasil pemulihan sejak dunia mengalami krisis ekonomi pada tahun 2008 dan 2009. Kawasan Asia merupakan salah satu kawasan dengan pemulihan cepat (PATA 2011). Untuk kawasan Asia Tenggara, walaupun belum bisa dibandingkan dengan negara di Asia Tenggara lainnya seperti Thailand yang masuk dalam 10 terbaik jumlah kunjungan wisatawan internasional pada tahun 2016 (UNWTO, 2017), Indonesia termasuk dalam negara yang mengalami peningkatan jumlah wisatawan pada tahun tersebut.

Jumlah wisatawan mancanegara yang berkunjung ke Indonesia pada tahun 2016 
mencapai 9,40 juta wisatawan. Peningkatan terjadi secara signifikan pada periode Januari sampai dengan Oktober 2017 sebesar 23,55\% atau 11,62 juta wisatawan (Badan Pusat Statistik, 2017). Peningkatan jumlah wisatawan ini dapat dijadikan salah satu penunjuk pengukuran bahwa adanya perkembangan industri pariwisata di sebuah negara (Isdaryono \& Mappile 2010). Dari segi ekonomi, pariwisata telah menjadi tumpuan pengembangan umum bagi banyak negara. Hal ini karena pariwisata internasional diakui memiliki dampak positif pada peningkatan jangka panjang pertembuhan ekonomi melalui berbagai saluran (Schubert, Brida \& Risso 2011).

Indonesia sempat mengalami keterpurukan dalam hal jumlah kunjungan wisatawan mancanegara. Tahun 2002 sampai dengan tahun 2006 merupakan masa-masa penuh tantangan bagi industri pariwisata Indonesia. Dimulai pada Oktober 2002 terjadinya pengeboman Bali I, diikuti kemudian musibah tsunami dan wabah Avian Flu pada akhir tahun 2004 dan awal tahun 2005 serta tragedi bom Bali II pada Oktober 200 (Nazmi 2008). Selain itu, isu keamanan yang berakhir pada diberlakukannya peringatan perjalanan oleh beberapa negara ikut mempengaruhi industri ini.

Berdasarkan hal tersebut, pemerintah Indonesia pada tahun 2008 kembali membangun dan melaksanakan program pariwisata yang diberi nama Visit Indonesia Year. Program ini pertama kali diperkenalkan pada tahun 1991 dimana merupakan proyek nasional yang terlaksana setelah terinspirasi dari keberhasilan Visit Thailand Year 1987 (Yamashita 1997). Pada akhir tahun 2007, Kementerian Pariwisata dan Ekonomi Kreatif Republik Indonesia, melalui menterinya menyelenggarakan soft launching Visit Indonesia Year 2008 sebagai sebuah tonggak kesiapan kembali Indonesia dalam bersaing di industri pariwisata internasional (www.budpar.go.id).

Semua strategi pariwisata yang dilakukan oleh pihak pemerintah Indonesia membawa pesan pemulihan citra dan membranding kembali Indonesia.

Hassan et al. (2010) mengatakan bahwa dalam sebuah kompetisi global di industri pariwisata, pelaku industri pariwisata harus dapat memaksimalkan destinasi untuk berkembang kuat, unik dan kompetitif. Oleh karenanya, pemasaran tempat dan branding destinasi telah menjadi sebuah alat yang strategis di seluruh dunia (Garcia et al. 2011).

Negara sama halnya dengan perusahaan atau organisasi dan bagian-bagian dari sebuah negara seperti sebuah perusahaan-perusahaan kecil. Oleh karenanya, kita dapat membuat brand apa pun sebagai sebuah prinsip yang boleh digunakan (Temporal 2004). Garcia et al. (2011) memberikan contoh beberapa negara yang melakukan strategi pembangunan brand destinasi. Diantara negara tersebut ialah Spanyol dengan "Smile! You Are ini Spain" dan Kolumbia dengan kampanye "Columbia is Passion" yang berhasil menaikkan jumlah kedatangan wisatawan internasional pada tahun 2006 ke Columbia. Tidak hanya sebuah negara, setiap kawasan dan daerah di dunia ini dapat melakukan branding, salah satunya ialah kota New York dengan "I love NY" yang dirancang oleh Milton Glaser pada tahun 1977 untuk melakukan promosi pariwisata.

Pelaksanaan kembali program pariwisata Visit Indonesia Year membuat pemerintah Indonesia melakukan strategi branding terhadap Indonesia. Pada tahun 2005, brand Indonesia diperkenalkan dengan nama "Indonesia, The Ultimate in Diversity". Selanjutnya pada tahun 2008, demi membawa semangat 100 Tahun Hari Kebangkitan Nasional, selama satu tahun tersebut Indonesia membawa tema "Celebrating 100 Years of National Awakening". Pada tahun 2009 dan 2010, program pariwisata ini tidak mempunyai brand tertentu, ia hanya menampilkan logo dan tulisan Visit Indonesia Year pada setiap media promosi. Selanjutnya pada tahun 2011 sampai dengan saat ini, pihak pemerintah Indonesia melalui kementeriannya membranding Indonesia dengan brand "Wonderful Indonesia".

Branding Indonesia melalui Wonderful Indonesia ialah cara untuk mengenalkan dan menjual Indonesia dengan membawa lima elemen pariwisata Indonesia yaitu alam, budaya, masyarakat, makanan, dan nilai keuangan. Kelima elemen ini berpadu dengan membawa pesan bahwa Indonesiaialahnegarayangmengagumkan. Strategi branding ini dipilih untuk menjadikan Indonesia lebih dikenal dan berbeda bagi para wisatawan. Hal ini sesuai dengan apa yang disampaikan 
oleh Morrison dan Anderson yang dikutip oleh (Qu, Kim \& Im 2011) bahwa branding destinasi ialah sebuah cara untuk mengomunikasikan sebuah identitas destinasi yang unik dengan membedakan sebuah destinasi dengan pesaing

Berdasarkan hal tersebut maka permasalahan penelitian ini adalah bagaimana persepsi wisatawan mancanegara terhadap brand Wonderful Indonesia? Persepsi diukur melalui elemen-elemen dalam brand Wonderful Indonesia yang terdiri dari keindahan alam, budaya Indonesia, keramahan masyarakat, makanan dan nilai keuangan.

\section{LITERATUR DAN METODOLOGI}

Wood (2008) memberikan definisi bahwa persepsi ialah sebuah proses aktif dari memilih, mengorganisasikan dan menginterpretasikan manusia, objek, kejadian, situasi dan aktiviti. Pada definisi ini ditumpukan bahwa persepsi ialah sebuah proses aktif yang terdiri dari tiga proses yang saling berhubungan yaitu memilih, mengatur dan menginterpretasikan. Secara umum persepsi dapat sering diartikan sebagai cara orang melihat dunia sekitarnya. Secara formal persepsi dapat didefinisikan sebagai suatu proses yang mana seseorang menyeleksi, mengorganisasikan, dan menginterpretasikan stimulus ke dalam suatu gambaran dunia yang bererti dan menyeluruh (Simamora, 2002).

Pemahaman mengenai persepsi adalah pengalaman mengenai sebuah objek, peristiwa, atau hubungan antara kejadian-kejadian yang diperoleh dengan membuat satu kesimpulan terhadap informasi serta menginterpretasikan sebuah pesan di dalamnya. Persepsi berhubungan dengan interpretasi seseorang terhadap sesuatu yang membentuk satu stimulus. Persepsi juga berhubungan dengan adanya harapan budaya, keperluan, suasana hati serta perilaku seseorang (Severin \& Tankard 2005).

Manakala Marconi (1997) mengatakan bahwa persepsi individu-individu adalah berdasarkan kepada apa yang mereka ketahui atau mereka fikri mengetahui. Berdasarkan kepada persepsi ini, individu-individu membeli, menjual, memilih, berjalan dan membuat semua keputusan dan mempengaruhi hidup mereka dari setiap hal di sekeliling mereka. American Marketing
Association mendefinisikan brand sebagai sebuah nama, istilah, tanda, simbol atau rancangan, atau sebuah kombinasi dari semua itu, dimaksudkan untuk mengetahui barang ataupun pelayanan dari satu penjual atau kelompok penjual dan untuk membedakan mereka dari para pesaing (Tasci \& Kozak 2006).

Branding destinasi didefinisikan sebagai pemilihan sebuah elemen-elemen campuran yang konsisten untuk mengetahui dan membedakannya melalui pembangunan citra positif. Contohnya bagaimana konsumen mempersepsi destinasi dalam fikiran mereka (Cai 2002). Efektifitas branding tempat tidak hanya berfungsi untuk memperkuat citra positif tetapi juga membantu melawan yang negatif dengan membentuk citra baru dan asosiasi. Selain itu, Pappu \& Quester (2010) mendefinisikan branding negara (juga dikenali sebagai branding bangsa) sebagai sebuah penciptaan dari membedakan identitas dalam sasaran pasar internasional melalui penggunaan nama, logo dan elemen brand lainnya.

Branding destinasi tidak hanya menjalankan nama, logo, reputasi atau status simbol akan tetapi juga atribut fisik sebuah destinasi, pengalaman, kualitas pelayanan yang diberikan dan daya tarik. Sedangkan branding kota atau suatu wilayah salah satu keperluan untuk mengidentifikasi daya tarik dan kegiatan untuk mengasosiasikan branda dengan tujuan untuk membangun brand image (Jayswal 2008).

Sejak tahun 2011, Indonesia memiliki sebuah brand pariwisata yaitu Wonderful Indonesia. Branding ini didasarkan kepada pengalaman ketika pulau Bali terpilih sebagai destinasi pariwisata terbaik dari Travel and Leisure Magazine New York, dimana penilaiannya merujuk kepada lima kriteria yaitu alam, budaya, masyarakat, makanan, dan uang (www.budpar.go.id). Pihak pemerintah Indonesia menjelaskan kelima kriteria ini ketika dipakai dalam membranding Indonesia. Wonderful Indonesia memiliki maksud sebagai berikut : 1) Keindahan alam; Indonesia memiliki tempat-tempat indah dan terkenal seperti Bali, Candi Borobudur, Bromo, Komodo, Raja Ampat dengan berbagai keindahan laut, gunung, hutan, serta tumbuhan dan hewan; 2) Budaya; Indonesia memiliki keindahan budaya yang berbagai dari Sabang sampai Merauke; 3) Keramahan 
masyarakat; masyarakat Indonesia sejak dahulu dikenal ramah dan murah senyum sehingga menarik bagi wisatawan; 4) Makanan; makanan atau kulinari Indonesia terkenal di dunia. Berbagai makanan merupakan bagian dari kekayaan budaya masyarakat Indonesia; dan 5) Nilai keuangan; nilai wang yang dikeluarkan setiap wisatawan dalam hal harga, menjadikan pelancongan Indonesia memiliki daya saing tinggi (www.budpar.go.id).

Persepsi terhadap brand Wonderful Indonesia diukur berdasarkan kepada pengetahuan dan pengalaman responden terhadap lima komponen pariwisata Indonesia dalam brand tersebut. Kelima komponen ini dimasukkan sebagai dimensi-dimensi dari brand Wonderful Indonesia. Dimensi keindahan alam, akan menanyakan pendapat responden tentang alam Indonesia yang didefiniskan pihak pemerintah Indonesia sebagai salah satu keunggulan Indonesia. Soalan yang diberikan dengan memberikan pertanyaan "Bagaimana anda melihat alam Indonesia?" Responden diminta untuk memberikan jawaban berdasarkan lima kategori jawaban yaitu 'sangat tidak indah', 'tidak indah', 'kurang indah', 'indah', dan 'sangat indah'. Keindahan alam Indonesia ini dilihat dari keindahan laut, gunung, pantai dan hutan. Skor lima diberikan untuk jawaban 'sangat indah' dan skor satu diberikan untuk jawaban 'sangat tidak indah'

Dimensi kedua ialah budaya, akan menanyakan persepsi responden mengenai budaya Indonesia yang diwakili oleh keragaman tarian, keragaman lagu tradisional, keragaman bahasa, adat istiadat dan keragaman kerajinan tangan. Setiap jawaban yang diberikan berdasarkan kepada kategori jawaban 'sangat menarik' sampai dengan 'tidak menarik'. Jawaban-jawaban bagi setiap soalan akan mendapatkan skor lima sebagai skor tertinggi dan satu sebagai skor terendah.

Selanjutnya dimensi ketiga ialah mengenai keramahan masyarakat Indonesia. Peneliti menanyakan kepada responden bagaimana persepsi branda mengenai keramahan masyarakat Indonesia. Responden diberikan pilihan jawaban berdasarkan lima kategori yaitu 'sangat ramah', 'ramah', 'kurang ramah', 'tidak ramah' dan 'sangat tidak ramah'. Setiap jawaban yang dipilih diberikan nilai di mana sangat ramah mendapat skor lima dan sangat tidak ramah mendapat skor satu.

Dimensi keempat ialah makanan. Soalan yang ditanyakan untuk melihat bagaimana persepsi responden mengenai makanan yang ada di Indonesia. Untuk soalan ini terdapat lima kategori jawaban mulai dari 'sangat baik' sampai dengan 'sangat tidak baik'. Setiap kategori jawaban akan mendapat skor lima untuk skor tertinggi dan skor satu untuk skor terendah.

Dimensi kelima ialah nilai keuangan. Soalan diberikan dengan menanyakan kepada responden bagaimana persepsi mereka terhadap nilai keuangan dari segi biaya penginapan, biaya taksi/ bus, harga makanan dan harga cinderamata. Setiap soalan diberikan jawaban berdasarkan empat kategori jawaban yaitu 'sangat murah', 'murah', 'mahal', dan 'sangat mahal'. Jawaban 'sangat murah' akan mendapatkan skor empat sebagai skor tertinggi dan 'sangat mahal' akan mendapat skor satu sebagai skor terendah.

Penelitian ini menggunakan pendekatan kuantitatif melalui survei terhadap $\quad 110$ wisatawan mancanegara. Pada penelitian ini sampel dipilih secara bertujuan (purposive sampling). Purposive sampling merupakan sampel non-acak yang menggunakan berbagai metode untuk mencari semua kemungkinan yang populasinya sangat luas (Neuman, 2013). Sampel wisatawan cirinya adalah wisatawan internasional yang datang ke Indonesia minimal satu kali dan akan pulang ke negaranya melalui bandara Soekarno-Hatta. Wisatawan yang dipilih berusia serendah-rendahnya 20 tahun.

\section{HASIL DAN PEMBAHASAN \\ Terpaan terhadap Brand Wonderful Indonesia}

Penelitian ini melihat terpaan kepada promosi brand Wonderful Indonesia sebagai sebuah brand pariwisata melalui kampanye Visit Indonesia Year. Tabel 1a menunjukkan frekuensi para wisatawan mendapat terpaan kampanye pariwisata Indonesia tersebut. Hasil pada tabel tersebut menunjukkan bahwa sangat sedikit wisatawan yang sering mendapat terpaan kampanye ini (4\%). Sebagian besar $(69 \%)$ mengaku tidak pernah mendapat terpaan kepada kampanye. Manakala 17\% jarang mendapat terpaan dan $10 \%$ hanya mendapat terpaan sekali sekali saja. 
Tabel 1a. Terpaan Kampanye Visit Indonesia Year

\begin{tabular}{lcc}
\hline & Bilangan & $\%$ \\
\hline Tidak pernah & 76 & 69 \\
Jarang & 19 & 17 \\
Sekali sekali & 11 & 10 \\
Sering & 4 & 4 \\
\hline
\end{tabular}

Tabel 1b menunjukkan bahwa sampel wisatawan banyak yang tidak mengetahui brand Wonderful Indonesia (61\%) dan kurang dari 50\% yang mengetahui brand ini. Apabila merujuk kembali kepada tabel 1a terdapat hubungan antara kedua hal ini. Boleh dirumuskan bahwa mereka yang sedikit dan kurang mendapat terpaan terhadap kampanye Visit Indonesia Year secara langsung juga akan sedikit saja mengetahui adanya brand Wonderful Indonesia.

Tabel 1b. Mengetahui brand pariwisata Wonderful Indonesia

\begin{tabular}{lcc} 
& Frekuensi & Persen (\%) \\
\hline Ya & 43 & 39 \\
\hline Tidak & 67 & 61 \\
\hline
\end{tabular}

Tabel 2. Saluran media untuk mendapatkan pesan pariwisata

\begin{tabular}{lccccc}
\hline & $\begin{array}{c}\text { Tidak } \\
\text { Pernah } \\
\%\end{array}$ & $\begin{array}{c}\text { Jarang } \\
\%\end{array}$ & $\begin{array}{c}\text { Sekali } \\
\text { sekali } \\
\%\end{array}$ & $\begin{array}{c}\text { Sering } \\
\%\end{array}$ & $\begin{array}{c}\text { Sangat } \\
\text { Sering } \\
\%\end{array}$ \\
\hline - Iklan di Televisi & 45 & 16 & 25 & 8 & 6 \\
- $\begin{array}{l}\text { Iklan di media cetak } \\
\text { Promosi pariwisata di } \\
\text { internet (iklan, laman }\end{array}$ & 44 & 17 & 24 & 11 & 4 \\
- $\begin{array}{l}\text { Sosial, dll) } \\
\text { Pameran pariwisata }\end{array}$ & 57 & 21 & 20 & 24 & 8 \\
- $\begin{array}{l}\text { Melalui keluarga } \\
\text { Melalui teman/ }\end{array}$ & 41 & 19 & 11 & 8 & 5 \\
- $\begin{array}{l}\text { Sahabat } \\
\text { Web-web pariwisata }\end{array}$ & 23 & 5 & 28 & 31 & 13 \\
$\quad \begin{array}{l}\text { dari pemerintah } \\
\text { Indonesia }\end{array}$ & 50 & 19 & 18 & 11 & 2 \\
Agen perjalanan & 47 & 15 & 19 & 10 & 9 \\
\hline
\end{tabular}

Saluran untuk Mendapatkan Informasi Pariwisata

Tabel 2 menunjukkan bahwa saluran antar pribadi yaitu pesan melalui sahabat merupakan saluran yang dominan digunakan oleh para wisatawan (31\%). Bologlu dan McCleary (1999) menunjukkan bahwa perbedaan jenis sumber informasi memiliki berbagai peringkat terhadap persepsi / penilaian kognitif. Rekomendasi dari rekan-rekan dan saudara adalah sumber yang paling penting dalam membentuk citra pariwisata.

Pada peringkat kedua, saluran internet melalui promosi pariwisata berupa iklan dan pesan dalam laman-laman sosial cukup banyak digunakan oleh wisatawan untuk memperoleh pesan (24\%). Akan tetapi hasil ini jauh berbeda dengan web promosi pariwisata yang dikelola oleh pemerintah Indonesia. Melalui saluran ini, wisatawan hanya memanfaatkannya sedikit saja (11\%). Kurangnya minat wisatawan dalam mencari pesan melalui web resmi milik pemerintah boleh menandakan bahwa web-web tersebut masih belum popular bagi para wisatawan.

Pada umumnya, selain dari saluran antar peribadi yaitu pesan melalui sahabat, kesemua saluran yang ada hanya sedikit saja memberikan 
manfaat untuk mendapatkan pesan mengenai pariwisata di Indonesia. Sebagian besar wisatawan sangat sedikit memperoleh pesan melalui iklan di televisi (8\%), iklan di media cetak (11\%), pameran pariwisata $(8 \%)$ dan melalui agen perjalanan $(10 \%)$. Hasil ini menunjukkan bahwa walaupun setiap tahun pemerintah Indonesia giat melakukan pemasaran di media elektronik dan cetak di dalam dan luar negeri, ianya belum menunjukkan hasil signifikan bagi wisatawan dalam memanfaatkannya untuk memperoleh pesan pariwisata di Indonesia.

Tabel 3. Persepsi terhadap keindahan alam Indonesia

\begin{tabular}{lccccc}
\hline & $\begin{array}{c}\text { Sangat } \\
\text { Tidak } \\
\text { Indah } \\
(\%)\end{array}$ & $\begin{array}{c}\text { Tidak } \\
\text { Indah } \\
(\%)\end{array}$ & $\begin{array}{c}\text { Kurang } \\
\text { Indah } \\
(\%)\end{array}$ & $\begin{array}{c}\text { Indah } \\
(\%)\end{array}$ & $\begin{array}{c}\text { Sangat } \\
\text { Indah } \\
(\%)\end{array}$ \\
\hline Wisatawan $(n=110)$ & & & & & \\
- Laut & 0 & 2 & 20 & 63 & 15 \\
- Gunung & 0 & 1 & 14 & 69 & 16 \\
- Pantai & 0 & 6 & 20 & 60 & 14 \\
- Hutan & 0 & 1 & 21 & 63 & 15 \\
\hline
\end{tabular}

Persepsi terhadap Elemen dalam Brand Pantai 6\% saja).

\section{Wonderful Indonesia}

\section{Persepsi terhadap Keindahan Alam Indonesia}

Tabel 3 menunjukkan persepsi wisatawan terhadap keindahan alam Indonesia. Dari empat komponen yang dilihat mayoritas mempersepsi bahwa alam Indonesia indah dengan persentase Gunung 69\%, Laut dan Hutan 63\%, serta Pantai $60 \%$. Akan tetapi, terdapat juga sebagian kecil wisawatan yang mempersepsi bahwa Alam Indonesia kurang indah (Hutan 21\%, Laut dan Pantai 20\%, serta Gunung 14\%). Selain itu, hanya sedikit yang mempersepsi alam Indonesia tidak indah (Gunung dan Hutan 1\%, Laut 2\%, serta

\section{Persepsi terhadap Budaya Indonesia}

Terdapat lima komponen yang dicantumkan untuk mempersepsi budaya Indonesia. Kelima komponen tersebut adalah tarian, keragaman lagu daerah, keragaman bahasa, adat istiadat dan keragaman kerajinan tangan. Tabel 4 memperlihatkan hasil persepsi wisatawan terhadap budaya Indonesia. Mayoritas wisatawan memepersepsi budaya Indonesia menarik (Tarian $69 \%$, keragaman lagu daerah dan adat istiadat $56 \%$, keragaman kerajinan tangan 54\%, serta keragaman bahasa $52 \%$ ).

Tabel 4. Persepsi terhadap Budaya Indonesia

\begin{tabular}{|c|c|c|c|c|c|}
\hline & $\begin{array}{c}\text { Sangat } \\
\text { Tidak } \\
\text { Menarik } \\
(\%) \\
\end{array}$ & $\begin{array}{l}\text { Tidak } \\
\text { Menarik } \\
(\%)\end{array}$ & $\begin{array}{c}\text { Kurang } \\
\text { Menarik } \\
(\%) \\
\end{array}$ & $\begin{array}{c}\text { Menarik } \\
(\%)\end{array}$ & $\begin{array}{c}\text { Sangat } \\
\text { Menarik } \\
(\%)\end{array}$ \\
\hline \multirow{5}{*}{$\begin{array}{ll}\text { Wisatawan }(n=110) \\
\text { - } & \text { Tarian } \\
\text { - } & \text { Keragaman lagu } \\
& \text { daerah } \\
\text { - } & \text { Keragaman } \\
& \text { bahasa } \\
\text { - } & \text { Adat istiadat } \\
\text { - } & \text { Keragaman } \\
& \text { kerajinan tangan }\end{array}$} & 2 & 4 & 14 & 69 & 11 \\
\hline & 3 & 3 & 28 & 56 & 10 \\
\hline & 1 & 3 & 32 & 52 & 12 \\
\hline & 3 & 4 & 20 & 56 & 17 \\
\hline & 1 & 3 & 14 & 54 & 28 \\
\hline
\end{tabular}


Selain itu, tabel 4 juga menunjukkan hasil bahwa terdapat cukup banyak wisatawan yang mempersepsi budaya Indonesia kurang menarik pada komponen keragaman bahasa yaitu sebesar $32 \%$. Disamping itu beberapa wisatawan juga mempersepsi budaya Indonesia kurang menarik yaitu pada keragaman lagu daerah $28 \%$, adat istiadat $20 \%$ serta tarian dan keragaman kerajinan tangan 14\%. Tabel tersebut juga memperlihatkan ada persepsi tidak menarik dan sangat tidak menarik dari wisatawan tentang budaya Indonesia.

\section{Persepsi terhadap Keramahan Masyarakat Indonesia}

Indonesia dikenal sebagai sebuah negara yang ramah. Oleh karenanya, pemerintah Indonesia memasukkan elemen ini sebagai salah satu hal mengagumkan untuk dipromosikan dalam brand Wonderful Indonesia. Hasil kajian menunjukkan bahawa kenyataan ini adalah benar. Tabel 5 menemukan bahwa persepsi wisatawan terhadap keramahan masyarakat Indonesia adalah sebesar $44 \%$ dan mempersepsi sangat ramah sebesar $43 \%$. Walau demikian, ternyata ada juga wisatwan yang mempersepsi masyarakat Indonesia kurang ramah (11\%) dan tidak ramah yaitu sebesar $2 \%$.

Tabel 5. Persepsi terhadap Keramahan Masyarakat Indonesia

\begin{tabular}{lccccc}
\hline & $\begin{array}{c}\text { Sangat } \\
\text { Tidak } \\
\text { Ramah } \\
(\%)\end{array}$ & $\begin{array}{c}\text { Tidak } \\
\text { Ramah } \\
(\%)\end{array}$ & $\begin{array}{c}\text { Kurang } \\
\text { Ramah } \\
(\%)\end{array}$ & $\begin{array}{c}\text { Ramah } \\
(\%)\end{array}$ & $\begin{array}{c}\text { Sangat } \\
\text { Ramah } \\
(\%)\end{array}$ \\
\hline $\begin{array}{l}\text { Wisatawan }(n=110) \\
\text { Keramahan }\end{array}$ & 0 & 2 & 11 & 44 & 43 \\
\hline
\end{tabular}

Tabel 6. Persepsi terhadap makanan Indonesia

\begin{tabular}{lccccc}
\hline & $\begin{array}{c}\text { Sangat } \\
\text { Tidak } \\
\text { Baik } \\
(\%)\end{array}$ & $\begin{array}{c}\text { Tidak } \\
\text { Baik } \\
(\%)\end{array}$ & $\begin{array}{c}\text { Kurang } \\
\text { Baik } \\
(\%)\end{array}$ & $\begin{array}{c}\text { Baik } \\
(\%)\end{array}$ & $\begin{array}{c}\text { Sangat } \\
\text { Baik } \\
(\%)\end{array}$ \\
\hline $\begin{array}{l}\text { Wisatawan }(n=110) \\
\text { Makanan Indonesia }\end{array}$ & 0 & 1 & 23 & 58 & 18 \\
\hline
\end{tabular}

\section{Persepsi terhadap Makanan Indonesia}

Makanan selalu menjadi salah satu hal yang dapat menarik wisatawan. Pelbagai jenis makanan popular cuba dipromosikan setiap negara ketika mengenalkan pelancongan negaranya. Antara makanan yang popular bagi para pelancong ialah Tom Yam Thailand, Laksa Penang Malaysia, Pizza Italia, Sushi Jepang, Bebek Peking China dan sebagainya Hasil penelitian pada tabel 6 menunjukkan bahwa persepsi wisatawan terhadap makanan Indonesia adalah baik (58\%). Walau begitu, tetap ada wisatawan yang mempersepsi kurang baik sebsar $23 \%$ dan tidak baik $1 \%$.

\section{Persepsi terhadap Nilai Keuangan di Indonesia}

Elemen selanjutnya yang menjadi bagian pada brand Wonderful Indonesia ialah elemen nilai keuangan. Kajian ini akan memaparkan bagaimana persepsi wisatwan dalam hal biaya penginapan, biaya transportasi, makanan dan cinderamata. Tabel 7 menunjukkan bahwa wisatawan secara umum mempersepsi bahwa biaya penginapan, biaya transportasi, makanan dan cinderamata di Indonesia adalah murah (Makanan 65\%, biaya transportasi $63 \%$, dan biaya penginapan 53\% serta cinderamata 51\%. Akan tetapi, cukup banyak juga yang mempersepsi bahwa nilai keuangan 
di Indonesia adalah mahal. Pada tabel tersebut terlihat wisatawan mempersepsi biaya penginapan mahal sebesar $37 \%$, dilanjutkan pada peringkat kedau adalah cinderamata sebesar $35 \%$.

Tabel 7. Persepsi terhadap Nilai Keuangan di Indonesia

\begin{tabular}{lcccc}
\hline & $\begin{array}{c}\text { Sangat } \\
\text { Mahal } \\
(\%)\end{array}$ & $\begin{array}{c}\text { Mahal } \\
(\%)\end{array}$ & $\begin{array}{c}\text { Murah } \\
(\%)\end{array}$ & $\begin{array}{c}\text { Sangat } \\
\text { Murah } \\
(\%)\end{array}$ \\
\hline Wisatawan $(n=110)$ & & & & \\
Biaya penginapan & 4 & 37 & 53 & 6 \\
Biaya transportasi & 5 & 18 & 63 & 14 \\
Makanan & 5 & 20 & 65 & 10 \\
Cinderamata & 6 & 35 & 51 & 8 \\
& & & & \\
\hline
\end{tabular}

Hasil penelitian diatas menunjukkan bahwa semua wisatawan mancanegara mempersepsi Indonesia baik. Pengukuran berdasarkan elemen dari brand Wonderful Indonesia sesuai dengan penelitian dari Echtner dan Ritchie (2003). Dalam kajiannya mereka mendapati bahwa citra destinasi dapat dipertimbangkan berdasarkan kepada komponen atribut dan komponen menyeluruh. Citra destinasi berdasarkan kepada ciri-ciri langsung dari pengamatan atau pengukuran seperti pemandangan, atrraction, penginapan, dan harga. Sementara yang lain dapat didasarkan pada ciriciri abstrak tidak berwujud seperti keramahan, keamanan, dan suasana.

\section{SIMPULAN}

Industri pariwisata telah menjadi sebuah industri yang bisa meningkatkan perekonomian sebuah negara. Oleh karenanya setiap negara semakin giat mengembangkan industri ini untuk menarik wisatawan datang berkunjung. Penciptaan citra negara melalui sebuah branding pariwisata dipilih sebagai salah satu strategi pemasaran. Tidak terkecuali negara Indonesia yang sejak tahun 2011 meluncurkan branding pariwisata Wonderful Indonesia.

Kewujudan industri pariwisata dalam memberikan dampak positif bagi peningkatan perekonomian suatu negara hendaknya menjadi sebuah perhatian. Oleh karenanya pelaksanaan program pariwisata seharusnya diberikan tumpuan yang lebih serius. Melalui program pariwisata Visit Indonesia Year, Indonesia sedang menunjukkan sebuah keseriusan membangun bidang ini. Berbagai promosi telah dilakukan, salah satunya dengan membentuk citra Indonesia melalui sebuah brand Wonderful Indonesia.

Hasil penelitian ini memberikan gambaran tentang saluran media yang digunakan wisatawan untuk mendapatkan informasi tentang Indonesia. Sebagian besar wisatawan mendapatkan informasi mengenai pariwisata Indonesia dari saluran antar pribadi yaitu melalui teman atau sahabat. Manakala web resmi yang dibuat oleh Kementerian Pariwisata dan Ekonomi Kreatif Republik Indonesia hanya dimanfaatkan oleh sebagian kecil wisatawan saja. Hal ini mungkin disebabkan oleh kurangnya promosi dari pihak kementerian untuk mempopularkan saluran media tersebut. Pihak pemerintah Indonesia terlalu banyak memanfaatkan berbagai saluran yang ada sehingga kurang melakukan perancangan media yang efisien.

Penelitian ini selanjutnya menemukan hasil yang berkaitan dengan terpaan terhadap kampanye pariwisata dan brand Wonderful Indonesia. Diandaikan bahwa mereka yang banyak mendapat terpaan kampanye akan mengetahui tentang brand ini. Hasil kajian menunjukkan bahwa sebagian besar wisatawan tidak pernah mendapat terpaan kampanye dan telah pasti ditemukan bahwa banyak wisatawan yang tidak mengetahui brand Wonderful Indonesia. Walaupun demikian sebagian besar wisatawan berpendapat bahwa brand ini bisa membuat mereka tertarik untuk datang ke Indonesia. 
Penelitian ini menemukan hasil tentang persepsi wisatawan mancanegara terhadap brand Wonderful Indonesia. Ada lima elemen yaitu keindahan alam, budaya, keramahan masyarakat, makanan dan nilai keuangan. Pada kelima elemen ini, wisatawan didapati memberikan persepsi yang positif. Wisatawan mempersepsi bahwa alam Indonesia indah, budaya Indonesia menarik, masyarakat Indonesia ramah, makanan Indonesia baik dan nilai uang di Indonesia adalah murah.

Wisatawan telah memiliki persepsi yang positif terhadap Indonesia. Persepsi positif pada keindahan alam, budaya, keramahan masyarakat, makanan dan nilai keuangan merupakan sebuah kekuatan Indonesia. Satu hal menarik yang menjadi perhatian utama adalah tentang keramahan masyarakat Indonesia. Hasil penelitian menunjukkan bahwa perkara yang berhubungan dengan keramahan menjadi sebuah nilai positif bagi Indonesia. Kepopularan Indonesia dari segi keramahannya telah memunculkan citra positif bagi Indonesia dan masyarakat Indonesia .

\section{DAFTAR PUSTAKA}

Badan Pusat Statistik. (2017). Jumlah Kunjungan Wisman. http://www.bps.go.id [26 Februari 2018].

Baloglu, S. \& McCleary, K.W. 1999. A Model of Destination Image Formation. Annals of Tourism Research 26(4): 868-897.

Cai, L.A. (2002). Cooperative Branding for Rural Destination. Annals of Tourism Research 29(3): 720-742.

Cutlip, S.M., Center, A.H \& Broom, G.M. 2006. Effective public relations. Ed.ke-9. Terj. Jakarta: Kencana Prenada Media Group.

Echtner, C.M. \& Ritchie, J.R.B. 2003. The Meaning and measurement of Destination Image. The Journal of Tourism Studies 14(1): 37-48.

Garcia, J.A., Gomez, A. \& Molina, A. (2011). A Destination-Branding Model: An Empirical Analysis Based on Stakeholders. Tourism Management: 1-16.

Goeldner, C.R. \& Ritchie, J.R.B. (2006). Tourism - Principles, Practices, Philosophies. Ed. ke-10. NJ: Wiley Hoboken.
Hassan, S.B., Hamid, M.S.A. \& Bohairy, H. (2010). Perception of Destination Branding Measures: A Case Study of Alexandria Destination Marketing Organizations. International Journal of EuroMediterranean Studies 3(2): 269-288.

Isdaryono. \& Mapille, R. (2010). Kunjungan Wisman ke Indonesia 2009: Pencapaian Target, Fluktuasi dan Distribusinya di Pintu Masuk. Jurnal Kepariwisataan Indonesia 5(1): 101-110.

Jayswal, T. (2008). Event Tourism: Potential to Build A Brand Destination. Proceeding of Conference on Tourism in India, hlm. 252262.

Kementerian Pariwisata dan Ekonomi Kreatif Republik Indonesia. (2010). Dampak Ekonomi Mikro Berdasarkan Neraca Satelit Pariwisata Nasional Tahun 20002010. http://www.budpar.go.id.

Kementerian Pariwisata dan Ekonomi Kreatif Republik Indonesia. (2010). Laporan Akuntabilitas Kinerja Instansi Pemerintahan (LAKIP). http://www. budpar.go.id.

Marconi, J. (1997). Image Marketing Public Perception to Attain Business Objective. Chicago: American Using Marketing Association.

Nazmi, M.F. 2008. Strategi Komunikasi Pemasaran Pelancongan di Indonesia Pasca Pengeboman Bali dan Tsunami: Suatu Analisis Komunikasi Pemasaran Terpadu (IMC). Tesis Master, Pusat Media dan Komunikasi, Universiti Kebangsaan Malaysia.

Neuman, W. L.2013. Metode Penulisan Sosial: Pendekatan Kualitatif dan Kuantitatif, $7^{\text {th }}$ edition. PT.Indeks: Jakarta.

Pappu, R. \& Quester, P. (2010). Country Equity: Conceptualization and Empirical Evidence. International Business Review 19: 276-29.

PATA. (2011). Sub Regional Trends 2011. http:// www.pata.org.html [3 Juni 2011].

Qu, H., Kim, L.H. \& Im, H.H. (2011). A Model of Destination Branding: Integrating the Concepts of The Branding and Destination 
Image. Tourism Management 32: 465-476.

Schubert, S.F., Brida, J.G. \& Risso, W.A. 2011.

The Impact of International Tourism

Demand on Economic Growth of Small

Economies Dependent on Tourism.

Tourism Management 32: 377-385

Severin, W.J. \& Tankard, J.W. (2005). Teori

Komunikasi: Sejarah, Metode, dan Terapan di dalam Media Massa. Edisi ke-5. Terj. Jakarta: Kencana.

Simamora, B. (2002). Panduan Riset Perilaku Konsumen. Jakarta: PT Gramedia Pustaka Utama.

Tasci, A.D.A. \& Kozak, M. (2006). Destination Brands vs Destination Image: Do We Know What We Mean?. Journal of Vacation Marketing 12(4): 299-317.

Temporal, P. (2004). The Brand Advantage: Public Sector Branding in Asia. Singapore: Times Editions.

UNWTO. (2017). UNWTO World Tourism
Highlights 2017 Edition. http://www. unwto.org.html [26 Februari 2018].

Wood, J.T. (2008). Communication Mosaic : An Introduction to The Field of Communication. CA : Thomson Wadsworth.

Yamashita, S., Eades, J.S. \& Din, K.H. (1997). Introduction: Tourism and Cultural Development in Asia and Oceania. Dlm. Yamashita, S., Dina, K.H. \& Eades, J.S. (pnyt). Tourism and Cultural Development in Asia and Oceania, hlm. 13-31. Bangi: Universiti Kebangsaan Malaysia.

Yamashita, S. (1997). Manipulating Ethnic Tradition: The Funeral Ceremony, Tourism, and Television Among The Toraja of Sulawesi, Indonesia. Dlm. Yamashita, S., Dina, K.H. \& Eades, J.S. (pnyt). Tourism and Cultural Development in Asia and Oceania, hlm. 83-103. Bangi: Universiti Kebangsaan Malaysia. 